\title{
Viral hijacking of host caspases: an emerging category of pathogen-host interactions
}

\author{
Patrick F Connolly ${ }^{1}$ and Howard O Fearnhead ${ }^{\star, 1}$
}

Viruses co-evolve with their hosts, and many viruses have developed mechanisms to suppress or modify the host cell apoptotic response for their own benefit. Recently, evidence has emerged for the opposite strategy. Some viruses have developed the ability to co-opt apoptotic caspase activity to facilitate their own proliferation. In these strategies, viral proteins are cleaved by host caspases to create cleavage products with novel activities which facilitate viral replication. This represents a novel and interesting class of viral-host interactions, and also represents a new group of non-apoptotic roles for caspases. Here we review the evidence for such strategies, and discuss their origins and their implications for our understanding of the relationship between viral pathogenesis and programmed cell death.

Cell Death and Differentiation (2017) 24, 1401-1410; doi:10.1038/cdd.2017.59; published online 19 May 2017

\section{Bullet Points}

Facts

- Executioner caspases have many non-apoptotic roles.

- Many viruses modulate the host cell apoptotic response.

- Some viruses utilize caspases to perform proteolytic processing of viral components.

- Caspase-3 and -7 predominate, although caspase-6 cleavage is also used.

\section{Open questions}

- How widespread is this phenomenon? No systematic experiments have yet been published.

- Can these examples be classified into functional categories?

- Did this 'hijacking' emerge once or several times during evolution?

- Are other modalities of cell death manipulated in this way?

Caspases can be classed into three broad categories (Table 1): those which function as the proteolytic executioners of apoptosis ('killer' caspases; including -3 and -7 ), those which serve to activate the executioner caspases (initiator caspases; including -8 and -10), and those which have roles in nonapoptotic processes, including inflammatory caspases such as $-1,-5$ and -11 (reviewed in Earnshaw et al. ${ }^{1}$ and Martinon and Tschopp $^{2}$ ).

In recent years it has become clear that 'killer' caspases have roles in diverse non-apoptotic processes, such as cell differentiation, migration and metastasis, and in signaling (reviewed in other articles in this issue). In these non-apoptotic processes, the extent of caspase activation or its subcellular localization is restricted in order to prevent cell death.
It is also important to note that even during apoptosis, caspases engage not only in destructive cleavage, but also engage in productive cleavage: cleavage which produces de novo activities of the substrate protein. This is achieved through several mechanisms (Figure 1), such as removal of autoinhibitory domains to produce constitutively active enzymes, cleavage of cytoplasmic localization sequences to facilitate nuclear membrane transition, or degradation of upstream inhibitory factors in metabolic pathways to activate downstream factors. ${ }^{3-6}$ Such productive cleavage allows apoptotic cells to engage signaling pathways until late in the cell death process.

Host cell apoptosis is a common response to viral infection (reviewed in Galluzzi et al. ${ }^{7}$ ). Apoptosis is typically considered a defense mechanism which kills the infected cell in order to protect the organism as a whole. As a result of this, there is a selection pressure in favor of viruses which have evolved mechanisms to block apoptosis. For example, several viruses encode Bcl-2 homologs or homologs of cFLIP which function to inhibit activation of apoptotic caspases and block death of the host cell. ${ }^{8-16}$

Interestingly, the inverse strategy can also be observed. Some viruses actually exploit host cell caspase activity to facilitate their own replication. These viruses encode gene products with canonical caspase cleavage motifs, and cleavage at these sites produces products with additional functions. This caspase cleavage is used, for example, to facilitate nuclear translocation of viral components, to activate viral-encoded host transcriptional modifiers, or to perform final maturation of virion particles (summarized in Table 2).

The involvement of host caspases in both viral and bacterial pathogenesis has previously been reviewed. ${ }^{17,18}$ However the present review focuses solely on examples of host caspase

\footnotetext{
${ }^{1}$ Pharmacology and Therapeutics, School of Medicine, National University of Ireland Galway, Galway, Ireland

${ }^{*}$ Corresponding author: H Fearnhead, Pharmacology and Therapeutics National University of Ireland, Galway, Biomedical Sciences Building Newcastle Road Room BMS-G029 NUI Galway, Dangan, Galway H91 CF50, Ireland; Tel: +353 91 495240. E-mail: howard.fearnhead@ nuigalway.ie

Received 17.1.17; revised 14.3.17; accepted 27.3.17; Edited by E Arama; published online 19.5.17
} 
Table 1 Conventional roles of caspases in cell death and inflammation

\begin{tabular}{lll}
\hline Functional group & Name & Ref \\
\hline Inflammatory response & Caspase-1 & 105 \\
& Caspase-4 & 106 \\
& Caspase-5 & 107 \\
& Caspase-11 & 108 \\
Apoptotic initiator & Caspase-12 & 109 \\
& Caspase-13 & 110 \\
& Caspase-2 & 111 \\
Apoptotic executioner & Caspase-8 & 112 \\
& Caspase-9 & 113 \\
Keratinocyte differentiation & Caspase-10 & 114 \\
Unknown functions & Caspase-15 & 115 \\
& Caspase-3 & 116 \\
& Caspase-6 & 117 \\
& Caspase-7 & 118 \\
& Caspase-14 & 119 \\
& Caspase-16 & 120 \\
& Caspase-17 & 120 \\
& Caspase-18 & 120 \\
\hline
\end{tabular}

Caspases are typically grouped into three major types: inflammatory caspases, apoptosis initiators and apoptosis executioners. Some caspases lie outside of the conventional groups. Caspase-14 appears to function only in keratinocyte differentiation (cornification). Capsases 16-18 have not yet been ascribed functions. ${ }^{119}$

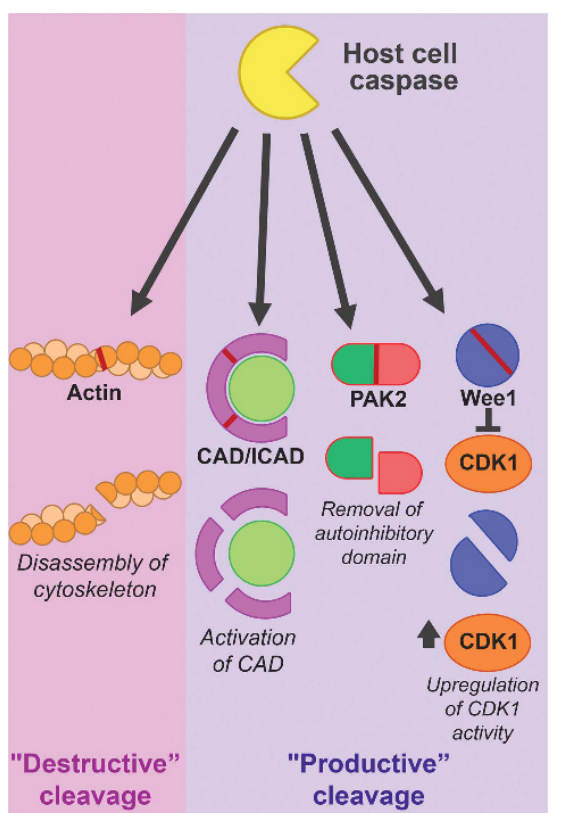

Figure 1 Examples of destructive and productive cleavage events by caspases during apoptosis. Executioner caspases can engage in destructive cleavage, such as disassembling the cytoskeleton through cleavage of actin filaments (left). However, executioner caspases can also engage in productive cleavage (right), in which signaling factors or enzymes are activated. This can be through degradation of bound inhibitor partners (ICAD/CAD), through removal of autoinhibitory domains (PAK2), or through inactivation of upstream inhibitory factors in biochemical pathways (Wee1/ CDK1)

cleavage of viral proteins rather than, for example, induction of apoptosis as progeny dissemination mechanism. This field has continued to develop, with new examples of viruscaspase interactions being published at an increased pace. As such, a review of the current state of this research is timely.

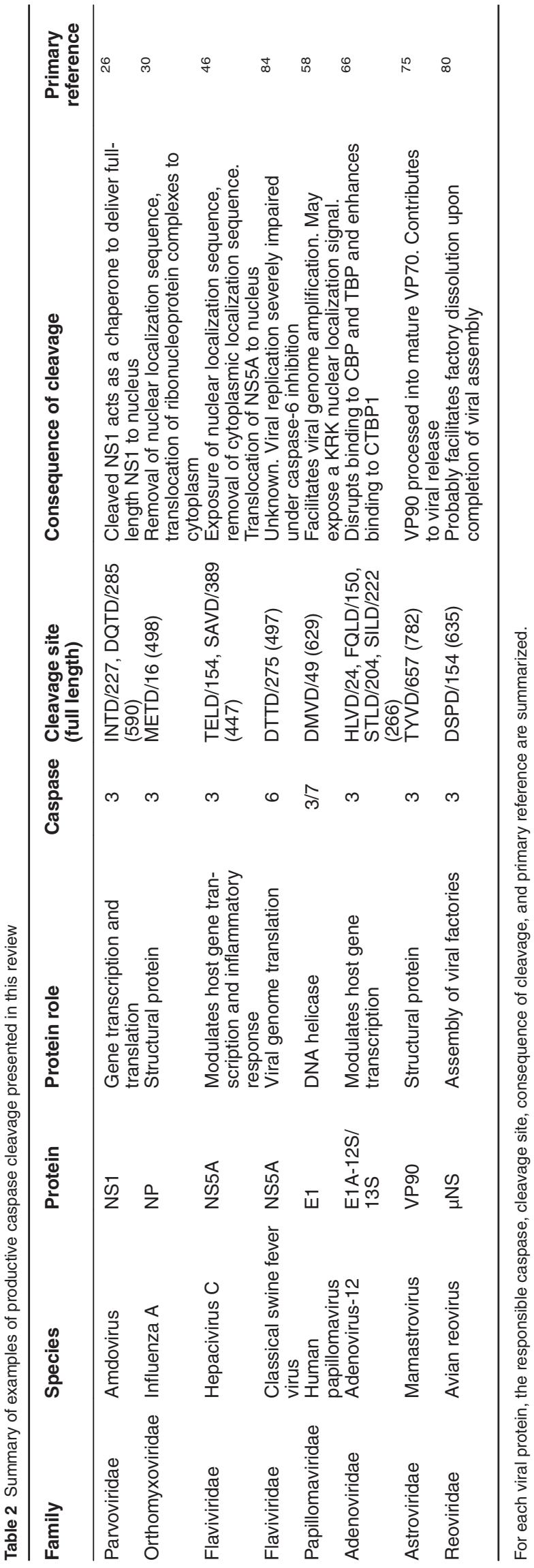




\section{Cleavage to Induce Nuclear-Cytoplasmic Trafficking of Viral Components}

Amdovirus. The Aleutian mink disease parvovirus (AMDV, Amdovirus) is a small, nonenveloped, (-)ssDNA virus. ${ }^{19}$ It harbors a $4.7 \mathrm{kbp}$ genome encoding two open reading frames, early ORF1 and late ORF2. ${ }^{20}$

ADV infects both newborn and adult minks, but with rather different cytopathologies. In newborn minks, infection leads to rampant, permissive replication, causing apoptosis of the host cell. In adult minks, ADV maintains itself through a more restrained low-level replication. ${ }^{21,22}$

The replication cycle of ADV is stereotypical of parvoviruses. After infection, the virion translocates to the nucleus, where the genome is uncoated. Upon entry into S phase, host cell DNA replication machinery is used to convert the singlestranded genome into a dsDNA template, from which the early genes are transcribed. ${ }^{23}$ These transcripts are transported to the cytoplasm, where translation and viral assembly occurs (reviewed in Luo and Qiu ${ }^{24}$ ).

ADV replication is caspase dependent, as pretreatment of CrFK feline kidney cells with the pharmacological caspase-3 inhibitor Ac-DEVD-CHO causes a marked inhibition of viral genomic amplification, gene expression and viral titer. ${ }^{25}$

One early ADV protein, NS1, involved in viral replication, has been shown to be cleaved by host caspases during infection. In CrFK cells, caspases-3 and -7 cleave the 590 residue protein at two sites nearby sites, (INTD/227) and (DQTD/285). ${ }^{26}$ The C-terminal domain localizes exclusively to the nucleus. This cleavage event is essential for nuclear reentry of full-length NS1, as engineered mutants without the cleavage sites do not translocate to the nucleus, and such viruses are largely replication defective. ${ }^{26}$

Full-length NS1 harbors a nuclear localization sequence near the $\mathrm{N}$-terminal which is revealed by caspase cleavage (Figure 2). Because cleavage is incomplete, a pool of uncleaved NS1 remains throughout the infection cycle. ${ }^{26}$ It has been postulated that the NLS-bearing C-terminal cleavage fragment oligomerizes with full length NS1 and facilitates nuclear re-entry of NS1.
Influenza A. Influenza viruses are members of the Orthomyxoviridae, a large family of $(-)$ ssRNA enveloped viruses which infect birds and mammals. There are currently three recognized subtypes of influenza, termed $A, B$ and $C .{ }^{27}$ All Influenza subtypes share similar overall structure, consisting of a lipid outer envelope, a capsid shell and a genomic ribonucleoprotein complex. ${ }^{28}$

Caspase activity is required for replication of several pathogenic H7N7, H3N2 and H1N1 strains. ${ }^{29-31}$ Inhibition of caspase activity using z-DEVD.FMK causes significant replication deficiencies in the highly pathogenic $A / B r a t i s l a v a /$ 79 (H7N7) strain propagated in kidney epithelial cells. ${ }^{29}$ Similarly, siRNA knockdown of caspase-3 or ectopic expression of the caspase inhibitor XIAP also strongly attenuate viral titer. Conversely, overexpression of procaspase-3 in infected cells enhances replication yields by 30 -fold. ${ }^{29}$

Additionally, overexpression of anti-apoptotic $\mathrm{Bcl}-2$ in infected MDCK cells hinders synthesis of viral proteins NP, $\mathrm{HA}$ and NS1, and causes incorrect viral surface glycosylation. ${ }^{32}$ Knockdown of pro-apoptotic Bax or Bik also leads to decreased viral titer, due to a defect in nuclear export of ribonucleoprotein complexes. ${ }^{33,34}$ Together, these data suggest that the mitochondrial pathway of caspase activation is exploited for Influenza A replication.

Influenza A nucleoprotein (NP) is cleaved by caspase-3 at (METD/16). ${ }^{30,31,35}$ This motif is highly conserved among human pathogenic $\mathrm{H} 1 \mathrm{~N} 1, \mathrm{H} 3 \mathrm{~N} 2$, and H2N2 strains. Cleavage produces a $3 \mathrm{kDa} \mathrm{N}$-terminal fragment. NP harbors and NLS within this N-terminal fragment (residues $3-13) .{ }^{36}$ Thus, it seems likely that host caspase-mediated removal of the NLS allows the assembled RNP complex to be transported to the cytoplasm (Figure 2). The decrease in replication efficiency upon caspase inhibition is attributed to the retention of ribonucleoprotein complexes in the nucleus. ${ }^{29}$

Interestingly, avian-like influenza A strains lack the NP caspase motif, instead harboring a $D_{16}>G$ substitution. It has been suggested that this difference is important for host range determination, as substitution of the avian-like sequence into a mammalian $\mathrm{H} 1 \mathrm{~N} 1$ isolate reduced lethality by 68 -fold in MDCK cells. ${ }^{37}$

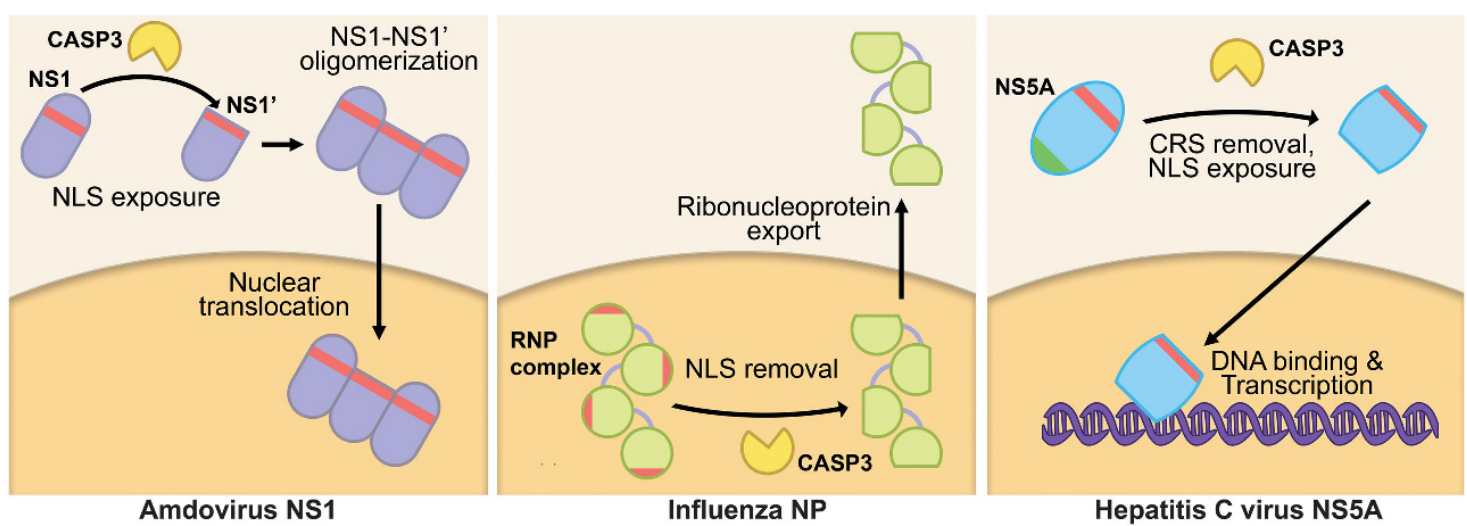

Figure 2 Examples of caspase cleavage inducing nuclear-cytoplasmic translocation of viral proteins. Left: Caspase processing of Amdovirus NS1 reveals an N-terminal nuclear localization sequence. Cleaved NS1 oligomerizes with full-length NS1 and facilitates nuclear entry. Center: Influenza A nucleoprotein is cleaved by caspase-3 to remove a nuclear localization sequence. This allows export of ribonucleoprotein complexes to the cytoplasm. Right: Hepacivirus C NS5A is cleaved at two positions to remove an N-terminal cytoplasmic retention sequence and to reveal a C-terminal Nuclear Localization Sequence, facilitating nuclear entry of NS5A 
Influenza B NP (64 kDa) also harbors a caspase-3-like cleavage motif (MDID/7) which is highly conserved. This protein is also cleaved in cells infected with the $\mathrm{B} / \mathrm{HK} / 72$ strain, producing a $55 \mathrm{kDa}$ C-terminal truncation. ${ }^{30,38}$ This may suggest that caspase-mediated cleavage of NP is not restricted to Influenza A strains.

Hepatitis C virus. Hepatitis $\mathrm{C}$ virus ( $\mathrm{HCV})$ is a member of the Flaviviridae, a family of nonenveloped (+)ssRNA viruses. $\mathrm{HCV}$ is not vector borne, but transmitted directly through bodily fluids. The virus is non-integrating, and can cause both acute and chronic pathologies. It is a causative agent of viral hepatitis, and can lead to liver failure and hepatocellular carcinoma. $^{39}$

The genome is encoded on a single RNA strand of $\sim 10 \mathrm{kbp}$. This is directly translated as a large polyprotein, which is processed into individual proteins by both host and viral proteases. $^{40}$

$\mathrm{HCV}$ gains entry to the target hepatocyte through clathrinmediated endocytosis. Replication takes place in lipid-bound compartments in the cytoplasm. Viral RNA polymerase transcribes a dsRNA template of the genome, from which positive-strand copies can be made. The virion is assembled on the surface of the viral factory membrane. After assembly, the virus is released via a non-lytic mechanism. ${ }^{41,42}$

Expression of the HCV core protein induces host caspase activity. ${ }^{43,44}$ Activated caspase- 3 then cleaves the nonstructural protein $5 \mathrm{~A}$ (NS5A). ${ }^{45}$ Cleavage is ablated by treatment of cells with the pan-caspase inhibitor z-VAD.FMK, and enhanced in cells treated with the apoptotic stimuli TNF- $a$ and cycloheximide.

Cleavage of the 447 residue NS5A protein occurs at two sites, one near the N-terminal (TELD/154) and the other near the C-terminal (SAVD/389). ${ }^{46}$ This cleavage both removes an $\mathrm{N}$-terminal cytoplasmic retention sequence (1-21), and exposes a C-terminal nuclear localization sequence (354362 ), resulting in the nuclear translocation of cleaved $\mathrm{NS} 5 \mathrm{~A}^{45,46}$ (Figure 2). This cleavage-induced nuclear translocation is required for $\mathrm{HCV}$ replication. ${ }^{47}$

Nuclear NS5A alters host cell transcription through modulation of transcription factor activity. NS5A activity leads to repression $\mathrm{p} 21^{\mathrm{WAF} 1}$ and expression of human proliferating cell nuclear antigen (PCNA), which together induces host cell proliferation. ${ }^{48}$ Nuclear NS5A also binds to the promoter sequences of host genes that are known to be important for HCV replication, such as IL-8, LT $\beta$ and NUAK2. ${ }^{47}$ Interestingly, nuclear NS5A also dampens host cell apoptotic response by inhibiting expression of p53 and Bax, while activating antiapoptotic Bcl-2. ${ }^{49-51}$

A model emerges in which $\mathrm{HCV}$-induced caspase activity is used to facilitate the nuclear translocation of NS5A. In the nucleus, NS5A alters host gene expression to force the host cell into a state of proliferation, while also disrupting the host apoptotic response. This represents an elegant mechanism in which a virus induces caspase activity to facilitate replication, only to later shut down the apoptotic response to prevent death of the host cell.

\section{Cleavage which Influences DNA Replication and Gene Transcription}

Human papillomavirus. Human papillomavirus (HPV) is a nonenveloped dsDNA virus of significant clinical interest. There exist more than 100 HPV subtypes, although only a subset of these cause are pathogenic. ${ }^{52}$ The pathogenic variants are grouped into two categories; low-risk (LR) subtypes which cause benign or squamous papillomas, and high-risk (HR) subtypes which can cause malignant cancers. $^{53}$

HPV encodes seven early nonstructural proteins (E1-E7), as well as two late structural proteins (L1 and L2). ${ }^{54}$ The nonstructural proteins include apparatus for viral genomic replication and viral encapsidation, as well as for arresting the host cell cycle, induction of cell differentiation, and regulation of apoptosis. ${ }^{55}$ The viral genome is capable of self-replication, and regulates this activity to maintain a viral load of $\sim 100$ copies per cell. ${ }^{56,57}$

It has been shown that host caspases-3, -7, and -9 are induced during infection of the high-risk HPV-31 subtype. ${ }^{58}$ This caspase activation is prevented from proceeding to a full apoptotic phenotype through the anti-apoptotic activity of E6, which inactivates p53, FADD and procaspase-8. ${ }^{59-61}$ HPVinduced caspase activity is necessary for viral genome amplification, as treatment with the caspase inhibitor z-DMQD.FMK strongly inhibited viral episome amplification. ${ }^{58}$

The HPV-31 helicase protein E1 is cleaved by host caspase-3 at (DMVD/49), both in a cell-free system with recombinant caspase-3, and in apoptotic cells transfected with $\mathrm{E} 1{ }^{58}$ Cells transfected with uncleavable mutant $\mathrm{E} 1$ genomes showed a substantial inhibition in genomic replication, similar to the effects of caspase inhibition, suggesting that E1 cleavage is a key event in viral replication.

Interestingly, the DMVD cleavage site is conserved among high-risk genital HPV strains, including the highest-risk strains $-16,-18,-31,-45$, but is not found among low-risk strains. This may suggest that this caspase cleavage event is selectively important for the pathogenesis of high-risk strains. The presence of a caspase cleavage site may be useful as a diagnostic marker for differentiating high- and low-risk strains.

Adenovirus. Adenoviruses are nonenveloped dsDNA viruses which infect a wide range of animals. In humans, adenovirus infection can results in fever, pharyngitis, conjunctivitis, bronchitis and pneumonia. ${ }^{62}$ There are more than 50 known pathogenic subtypes of human adenovirus, which are classified into seven species, $A-G .{ }^{63}$

The genome consists of a single linear chromosome of $\sim 36 \mathrm{kbp}$. The adenovirus genome encodes early replication genes and late capsid packaging and maturation genes. Alternative splicing is used to produce over thirty peptides. ${ }^{64}$

Adenovirus gains entry to the host cell through receptormediated endocytosis. The virion escapes the endosome during acidification and migrates to the nucleus, where the DNA genome is uncoated and transits through the nuclear pore complex. ${ }^{65}$

Caspase activity is required for adenovirus replication. Treatment of infected HeLa cells with the pan-caspase inhibitor z-VAD.FMK substantially increased viral production, 
while also causing a defect in viral progeny release. ${ }^{8}$ Caspase inhibition also slows down the rate of infection, as complete infection is observed after $72 \mathrm{~h}$ in z-VAD-treated cells, compared to $48 \mathrm{~h}$ in control cells. ${ }^{8}$

Mechanistically, it has been shown that the large adenoviral E1A gene products, 12S and 13S, are cleaved by caspase-3. Cleavage first occurs at (HLVD/24), removing an N-terminal sequence, then at (FQLD/150). This second cleavage produces two large fragments. The $\mathrm{N}$-terminal fragment is rapidly degraded, while the $\mathrm{C}$-terminal fragment undergoes further cleavage at (STLD/205) and (SILD/243). ${ }^{66}$

E1A gene products have several roles during adenovirus infection. One of these roles is to modulate host gene transcription. It has been shown that caspase cleavage of $\mathrm{E} 1 \mathrm{~A}$ products disrupts binding of $\mathrm{E} 1 \mathrm{~A}$ to host transcriptional activators CBP and TBP. ${ }^{66}$ Cleavage also enhances binding of $\mathrm{E} 1 \mathrm{~A}$ to the host transcriptional repressor CtBP1. ${ }^{66}$ Based on the targeted sites, cleavage likely also disrupts $\mathrm{E} 1 \mathrm{~A}$ binding to known interaction partners such as p21 and p27, ${ }^{67}$ though these have not yet been experimentally tested. Together, this suggests that viral-induced caspase activity alters that transcription factor binding activity of $\mathrm{E} 1 \mathrm{~A}$ proteins, and that this is necessary for viral replication.

\section{Cleavage to Facilitate Viral Release}

Astrovirus. The Astroviridae are a family of (+)ssRNA viruses first described in $1975 .{ }^{68}$ They are divided into two genera; the Avastroviridae which infect birds, and the Mamastroviridae which infect mammals. ${ }^{69}$ They are the causative agent of some forms of viral gastroenteritis. ${ }^{70}$

The genome consists of a single, non-segmented RNA strand of $6.8-7 \mathrm{kbp}$. The genome contains three overlapping


Figure 3 Examples of caspase cleavage to facilitate viral progeny release. (a) Model of Astrovirus release from host cell. Caspase- 3 cleaves capsid protein VP90. This either facilitates viral release from cytoplasmic viral factories, or facilitates cellular egress of mature viral particles. (b) Model of Avian reovirus release from host cell. Caspase cleavage of $\mu$ NS induces dissolution of viroplasm inclusion factories in the cytoplasm, leading to mature virion formation and viral egress
ORFs, which encode a serine protease (Nsp1a), an RNA polymerase (Nsp1ab), and one structural capsid protein (VP90). ${ }^{71}$

The infection strategy is similar to that of other nonenveloped RNA viruses (reviewed in Mendez et al. ${ }^{72}$ ). The virus enters the host cell through receptor-mediated endocytosis. In the cytoplasm, the virus uncoats and the genome is released. Viral factories are produced using ER-derived membrane vesicles. The positive-stranded RNA genome is directly translated, while the genome is replicated by way of a dsRNA intermediate. ${ }^{73}$ The assembled virus is released through a non-lytic mechanism. ${ }^{67}$

Host caspase activity is required during the Astrovirus life cycle. In Caco-2 epithelial adenocarcinoma cells infected with human Astrovirus-8, the activities of both initiator caspases-4, -8 and -9 , and executioner caspases -3 and -7 are detected $\sim 12 \mathrm{~h}$ post infection, and siRNA knockdown of caspase-3 or inhibition with Ac-DEVD-CHO strongly attenuates viral release. $^{74}$

It has been shown that host caspase-3 is responsible for the proteolytic processing of capsid protein VP90 to its mature form, VP70. ${ }^{75}$ This cleavage occurs at (TYVD/657). Blocking caspase activity using z-VAD.FMK inhibits this cleavage event, while treatment with the apoptotic stimulus TRAIL enhances VP90 processing. Inhibition of caspase activity leads to accumulation of viral particles within the cell and a defect in viral release. ${ }^{75}$ Caspase-mediated processing of VP90 is an essential step in Astrovirus maturation, although it is not currently clear whether this cleavage facilitate the release of virions from the viral factory membrane, or facilitates a later step in virion release from the cell. (Figure 3). ${ }^{71}$

\section{Avian reovirus}

Avian reovirus (ARV) belongs to the Reoviridae family of dsRNA viruses. ARV typically infects broiler chickens, causing a number of pathologies including blue wing disease. ${ }^{76}$ Once infected, the virus quickly spreads through all tissues, particularly the skin and musculature, inducing focal skin hemorrhages, arthritis, and stunted growth. ${ }^{76,77}$

The ARV genome is composed of ten segments of dsRNA, with a combined size of $23.5 \mathrm{kbp}$, which encode ten structural proteins and five nonstructural proteins. ${ }^{78}$ Viral replication takes place in the cytoplasm, and virion assembly takes place in factory-like viroplasm inclusions containing the nonstructural proteins and genomic RNA (Figure 3). ${ }^{79}$ Progeny release is facilitated through a lytic, apoptosis-driven mechanism. ${ }^{80}$

In chick embryonic fibroblasts and HeLa cells infected with ARV strain S1133, nonstructural protein $\mu \mathrm{NS}$ is cleaved by host caspases at (DSPD/154), removing an N-terminal domain. ${ }^{80}$ Treatment with the pan-caspase inhibitor Q-VDOPh prevents this $\mu \mathrm{NS}$ processing. Cleavage is performed solely by caspase-3, and not by caspase-7, as indicated by cell-free experiments. ${ }^{80}$ Like the example of Astrovirus above, caspase inhibition leads to a drastically reduced extracellular viral titer, suggesting a defect in viral release.

$\mu \mathrm{NS}$ is a conserved nonstructural protein among reoviruses. The $\mu \mathrm{NS}$ of ARV has an important role in the formation of viroplasm factories. ${ }^{81,82}$ Since $\mu \mathrm{NS}$ processing happens relatively late in the infection cycle, it is possible that 
processing of $\mu \mathrm{NS}$ is responsible for dissociation of viral factories after virion assembly is complete (Figure 3). Supporting this, it has been shown that the cleaved forms of $\mu \mathrm{NS}$ associate less strongly with viral inclusions than the intact form. ${ }^{80}$ Further work is needed to test the functional significance of $\mu \mathrm{NS}$ cleavage in ARV pathogenesis.

\section{Cleavage with Unknown Functions}

Classical swine fever virus. Like the Hepatitis $C$ virus discussed above, Classical Swine Fever virus (CSFV) belongs to the Flaviviridae. CSFV is endemic in farmed pigs, and infection causes fever-like symptoms and skin lesions, often leading to rapid death of the infected animal. CSFV infection is highly contagious and is spread by direct animalto-animal transmission, as well as through aerosol and fomites. ${ }^{83}$

Like other flaviviruses, the (+)ssRNA genome is translated as a single large polypeptide that is subsequently processed into early and late proteins. Nonstructural protein 5A (NS5A) harbors a typical caspase cleavage motif at (DTTD/272), which is cleaved by caspase- 6 in swine testes cells. ${ }^{84}$

This cleavage is blocked by the caspase-6-specific inhibitor z-VEID.FMK, and also by shRNA-mediated downregulation of caspase-6. Disrupting this cleavage event through z.VEID. FMK treatment decreased viral yield by 7.9 -fold, while shRNA inhibition of caspase- 6 caused a 21.5 -fold reduction in extracellular viral titer. Intracellular viral titer was also decreased by 10 -fold, suggesting that the replication defect does not occur at the level of viral release, but at some stage of intracellular virion production. Together, these observations suggest that, similar to $\mathrm{HCV}$, cleavage of CSFV NS5A is required for proper viral replication.

Caspase- 6 is atypical in the fact that it is not activated directly by upstream initiator caspases during apoptosis, but relies on activation by the effector caspases-3 and $-7 .{ }^{85}$ That active caspase- 6 is present in CSFV-infected cells may suggest that caspases-3 or -7 are also active, or that caspase- 6 is induced through a non-canonical mechanism.

The function of NS5A cleavage is not yet known. This protein has roles in viral genomic translation and replication, and has been shown to interact with host translation elongation factor $1 \mathrm{~A}$. It also appears to be involved in folding of translated proteins through its interaction with Hsp70. Perhaps, like HCV NS5A, cleavage alters interactions between this protein and host transcription factors.

Other caspase-viral interactions. In this paper, we have focussed on examples of productive caspase cleavage of viral proteins. Interestingly, another distinct strategy of viral hijacking can be observed. Several viruses utilize host caspase activity as a tool to penetrate the nuclear membrane. The parvovirus Minute Virus of Mice (MVM) induces host caspase-3 activity. This activity is used to transiently permeablize the nuclear envelope through lamin cleavage, which allows nuclear entry of MVM capsids. ${ }^{86,87}$

Similarly, Influenza A-induced caspase activity leads to cleavage of nucleoporin 153 and enlargement of nuclear pores, facilitating nuclear export of ribonucleoprotein complexes. ${ }^{88}$
This appears to be a complementary strategy to the caspase cleavage-mediated NP export described above.

A third example of this strategy occurs with Simian Virus 40 (SV40). Upon infection, the SV40 capsid protein induces host cell caspase activity. This activity leads to perforation of the nuclear lamina by caspase-6, allowing nuclear entry of the SV40 capsid. ${ }^{89,90}$

Viral-encoded caspases. There are also examples of viruses which encode their own executioner caspases. Ascoviruses are a family of large dsDNA viruses which infect noctuid moths. Each of the four members of this family encodes a caspase-like protein.

The Spodoptera frugiperda ascovirus (SfAV-1a) caspase is expressed upon infection, and induces a modified apoptotic response. ${ }^{91}$ Apoptotic bodies are formed, but rather than disintegrate, these are converted into large virus-bearing vesicles. These vesicles facilitate viral dissemination through the blood. SfAV also encodes several IAP-like proteins, and these may contribute to modifying the apoptotic response induced by the viral caspase..$^{92}$

The Heliothis virescens ascovirus (HvAV-3e) caspase does not induce apoptosis, but is required for viral replication. ${ }^{93}$ During HvAV infection, the host actin fiber network is reorganized into bleb-like structures. ${ }^{94}$ These are reminiscent of the caspase-driven cytoskeleton remodeling seen during apoptosis. This process is required for host cell vesiculation and cytopathology. It is possible that the HvAV caspase is responsible for driving this actin reorganization.

\section{Discussion}

Several kinds of interaction between viruses and host cell caspases have historically been observed. Viruses can inhibit caspase activation in order to block apoptotic death of the host cell and prolong their window of replication. This can occur through expression of orthologs of anti-apoptotic Bcl or FLIP proteins. ${ }^{11,95}$ Alternatively, viruses have been known to induce host cell apoptosis in order to facilitate the spread of progeny virus, for example through the dissemination of viral-laden apoptotic bodies. ${ }^{96}$

In this review, evidence is presented for the existence of an emerging third class of virus-caspase interaction. In these strategies, viruses 'hijack' the proteolytic cleavage activity of host caspases to cleavage viral proteins in order to facilitate viral replication.

Functional categories emerging from the examples presented. Several types of strategy can be observed from the examples presented here. In the first, caspase activity is used to facilitate nuclear-cytoplasmic trafficking of viral proteins, achieved through the removal or exposure of nuclear localization sequences or cytoplasmic retention sequences. Of the examples presented here, these are the most robust and best supported by experimental data. A second strategy is the cleavage of viral proteins which influence DNA replication and gene transcription through the modification of nonstructural proteins. A third strategy is the use of host caspase activity to perform final maturation steps in viral assembly and release. 
Table 3 Survey of predicted caspase-3 cleavage sites in endemic human pathogenic viruses

\begin{tabular}{|c|c|c|c|c|c|c|}
\hline Group & Family & Species/strain & Protein name & Motif & Position & Protein length \\
\hline III/dsRNA & Reoviridae & Rotavirus A (B4106) & $\begin{array}{l}\text { VP6 } \\
\text { RNA-directed RNA polymerase }\end{array}$ & $\begin{array}{l}\text { DLYD } \\
\text { DKKD } \\
\text { DEID } \\
\text { DQVD } \\
\text { DSDD } \\
\text { DSDD } \\
\text { DFVD } \\
\text { DVDD } \\
\text { DGDD } \\
\text { DSED }\end{array}$ & $\begin{array}{c}182 \\
39 \\
143 \\
109 \\
158 \\
168 \\
93 \\
357 \\
632 \\
770\end{array}$ & $\begin{array}{l}492 \\
317 \\
175 \\
198\end{array}$ \\
\hline $\mathrm{IV} /(+)$ ssRNA & Coronaviridae & SARS coronavirus & $\begin{array}{l}\text { Membrane protein } \\
\text { Replicase } 1 \mathrm{ab}\end{array}$ & $\begin{array}{l}\text { DIKD } \\
\text { DLGD } \\
\text { DWLD } \\
\text { DYLD } \\
\text { DGAD } \\
\text { DSLD } \\
\text { DHVD } \\
\text { DLYD } \\
\text { DAVD } \\
\text { DVSD } \\
\text { DLGD } \\
\text { DEDD }\end{array}$ & $\begin{array}{c}162 \\
147 \\
983 \\
1170 \\
1580 \\
2276 \\
3498 \\
5884 \\
277 \\
557 \\
1150 \\
1242\end{array}$ & $\begin{array}{l}221 \\
7073\end{array}$ \\
\hline IV/(+)ssRNA & Flaviviridae & Dengue virus (Thailand/0168/1979) & Genome polyprotein & $\begin{array}{l}\text { DALD } \\
\text { DAID }\end{array}$ & $\begin{array}{l}2119 \\
1995\end{array}$ & 3391 \\
\hline $\mathrm{IV} /(+) \operatorname{ssRNA}$ & Flaviviridae & West nile virus & Genome polyprotein & $\begin{array}{l}\text { DVTD } \\
\text { DPED } \\
\text { DDWD }\end{array}$ & $\begin{array}{c}144 \\
187 \\
1905\end{array}$ & 3430 \\
\hline $\mathrm{IV} /(+)$ ssRNA & Flaviviridae & Yellow fever virus (Ivory Coast/1999) & Genome polyprotein & $\begin{array}{l}\text { DSDD } \\
\text { DKTD }\end{array}$ & $\begin{array}{c}805 \\
2637\end{array}$ & 3411 \\
\hline $\mathrm{IV} /(+)$ ssRNA & Flaviviridae & Zika virus (Mr 766) & Genome polyprotein & $\begin{array}{l}\text { DRSD } \\
\text { DDVD } \\
\text { DFSD }\end{array}$ & $\begin{array}{l}140 \\
188 \\
486\end{array}$ & 3419 \\
\hline \multirow[t]{2}{*}{$\begin{array}{l}\text { IV } /(+) \text { ssRNA } \\
\text { IV } /(+) \text { ssRNA }\end{array}$} & \multirow[t]{2}{*}{$\begin{array}{l}\text { Picornaviridae } \\
\text { Togaviridae }\end{array}$} & \multirow[t]{2}{*}{$\begin{array}{l}\text { Coxsackie B3 (Nancy) } \\
\text { Rubella virus (BRDII) }\end{array}$} & $\begin{array}{l}\text { Genome polyprotein } \\
\text { Nonstructural polyprotein p200 }\end{array}$ & $\begin{array}{l}\text { DKVD } \\
\text { DDWD } \\
\text { DERD } \\
\text { DLTD }\end{array}$ & $\begin{array}{c}725 \\
208 \\
1148 \\
1750\end{array}$ & $\begin{array}{l}2185 \\
2116\end{array}$ \\
\hline & & & Structural polyprotein & $\begin{array}{l}\text { DPGD } \\
\text { DDAD }\end{array}$ & $\begin{array}{l}784 \\
844\end{array}$ & 1063 \\
\hline \multirow[t]{3}{*}{ V/(-)ssRNA } & \multirow[t]{3}{*}{ Filoviridae } & \multirow[t]{3}{*}{ Ebola virus (Mayinga-76) } & Envelope glycoprotein & $\begin{array}{l}\text { DFLD } \\
\text { DKID } \\
\text { DFVD }\end{array}$ & $\begin{array}{l}445 \\
622 \\
632\end{array}$ & 676 \\
\hline & & & $\begin{array}{l}\text { Matrix protein VP40 } \\
\text { Nucleoprotein }\end{array}$ & $\begin{array}{l}\text { DTID } \\
\text { DAND } \\
\text { DPDD } \\
\text { DDED } \\
\text { DEDD } \\
\text { DDAD }\end{array}$ & $\begin{array}{c}60 \\
229 \\
463 \\
494 \\
492 \\
576\end{array}$ & $\begin{array}{l}326 \\
739\end{array}$ \\
\hline & & & RNA-directed RNA polymerase L & $\begin{array}{l}\text { DCVD } \\
\text { DPHD }\end{array}$ & $\begin{array}{c}129 \\
1685\end{array}$ & 2212 \\
\hline V/(-)ssRNA & Filoviridae & Lake Victoria marburgvirus (Musoke/1980) & $\begin{array}{l}\text { Envelope glycoprotein } \\
\text { Nucleoprotein }\end{array}$ & $\begin{array}{l}\text { DDED } \\
\text { DAYD } \\
\text { DLND }\end{array}$ & $\begin{array}{l}265 \\
211 \\
461\end{array}$ & $\begin{array}{l}681 \\
695\end{array}$ \\
\hline \multirow[t]{2}{*}{ V/(-)ssRNA } & \multirow[t]{2}{*}{ Paramyxoviridae } & \multirow[t]{2}{*}{ Measles virus (Edmonston) } & $\begin{array}{l}\text { Hemagglutinin glycoprotein } \\
\text { Nucleoprotein }\end{array}$ & $\begin{array}{l}\text { DFRD } \\
\text { DDPD } \\
\text { DEAD } \\
\text { DPQD }\end{array}$ & $\begin{array}{c}401 \\
96 \\
128 \\
487\end{array}$ & $\begin{array}{l}617 \\
523\end{array}$ \\
\hline & & & $\begin{array}{l}\text { Phosphoprotein } \\
\text { RNA-directed RNA polymerase L }\end{array}$ & $\begin{array}{l}\text { DVQD } \\
\text { DVLD } \\
\text { DPYD } \\
\text { DEQD } \\
\text { DRFD }\end{array}$ & $\begin{array}{c}317 \\
317 \\
512 \\
583 \\
1605\end{array}$ & $\begin{array}{l}507 \\
2183\end{array}$ \\
\hline \multirow[t]{3}{*}{$\mathrm{V} /(-)$ ssRNA } & \multirow[t]{3}{*}{ Rhabdoviridae } & \multirow[t]{3}{*}{ Vesicular stomatitis virus (Ogden/Concan) } & $\begin{array}{l}\text { Matrix protein } \\
\text { Nucleoprotein }\end{array}$ & $\begin{array}{l}\text { DLYD } \\
\text { DGLD } \\
\text { DKAD }\end{array}$ & $\begin{array}{c}55 \\
180 \\
272\end{array}$ & $\begin{array}{l}229 \\
422\end{array}$ \\
\hline & & & Phosphoprotein & $\begin{array}{l}\text { DSVD } \\
\text { DNLD }\end{array}$ & $\begin{array}{c}5 \\
5 \\
18\end{array}$ & 274 \\
\hline & & & RNA-directed RNA polymerase $L$ & $\begin{array}{l}\text { DFGD } \\
\text { DLID } \\
\text { DLSD } \\
\text { DLSD } \\
\text { DYVD }\end{array}$ & $\begin{array}{c}442 \\
460 \\
1699 \\
1738 \\
1846\end{array}$ & 2109 \\
\hline \multirow[t]{2}{*}{$\mathrm{Vl} / \mathrm{ssRNA-RT}$} & \multirow[t]{2}{*}{ Retroviridae } & \multirow[t]{2}{*}{ Human Immunodeficiency Virus 1 (HXB2) } & Gag-pol & $\begin{array}{l}\text { DYVD } \\
\text { DNSD }\end{array}$ & $\begin{array}{l}298 \\
1403\end{array}$ & 1435 \\
\hline & & & Nef & DILD & 111 & 206 \\
\hline
\end{tabular}

Sequences were obtained from the Uniprot repository. Caspase-3 cleavage motifs of the sequence 'DXXD' were identified. These were cross referenced against the PMAP-CutDB, ${ }^{107}$ a database of experimentally verified caspase cleavage motifs. 
Cleavage events with unknown or cryptic functions. With some examples, the functional consequence of caspase cleavage is unknown. Classical swine fever virus NS5A is cleaved by host caspase- 6 , and inhibition of this event leads to a strong inhibition of intracellular viral replication, but the reason for this is still obscure.

Some other examples exist of viral proteins which are cleaved by host caspases, but the consequence of whose cleavage is not completely understood. The nucleocapsid protein of Crimean-Congo hemorrhagic fever virus, a deadly bunyavirus, is cleaved by caspase- 3 and cleavage limits viral replication. $^{97}$

The penton capsomere proteins of the Theiler's murine encephalomyelitis virus (TMEV) are cleaved by caspase-3 activity, but the direct effect of this cleavage on viral replication is unclear. $^{98}$

The nucleoprotein (NP) of Junin Virus is cleaved by caspase3. Interestingly, expression of NP suppresses the activity of caspase-3 in camptothecin-treated cells. This is taken to indicate that NP can act is a decoy substrate for caspase-3, intercepting and blocking the apoptotic response to infection. ${ }^{99}$

The origins of caspase hijacking strategies. A taxonomic analysis of the examples presented here shows that this phenomenon is not restricted to any particular virus group, but are found distributed among ssRNA, dsRNA, ssDNA and dsDNA viruses. Because of this, the strategy of exploiting host cell death machinery to facilitate viral replication likely emerged several times during evolution.

Cell death is a common response to viral infection in multicellular organisms. It is therefore a cellular state to which many viruses are exposed, and to which they must adapt. Given the prolific, unrestrained nature of killer caspase activity within apoptotic cells, it is perhaps not surprising that many viruses have adapted to use this proteolytic activity for their own benefit.

Latent viruses: a balance between apoptosis inhibition and caspase activation. Viruses can generally be categorized into two groups: those which are capable of remaining within the host cell in a persistent, latent state; and those which are constitutively lytic. Latency often occurs through integration into the host genome. Latent viruses generally prevent the death of the host cell, often through expression of anti-apoptotic factors. Several of the viruses described in this review; namely HPV, KSHV and SV40, are able to persist in latent, integrated states,

A question presents itself; how can latent viruses prevent host cell death, while simultaneously taking advantage of caspase activity? In other systems, it has been shown that sub-lethal caspase activation can be utilized to achieve nonapoptotic outcomes such as cell differentiation (reviewed in Connolly et al. ${ }^{100}$ ). A similar mechanism of restricted caspase activation may be used by persistent viruses. Through the activity of viral anti-apoptotic factors, host caspase activity may be restricted spatially or temporally, in magnitude.

Viral hijacking of non-apoptotic forms of cell death. Interestingly, other modalities of cell death are also 'hijacked' to facilitate viral replication. Treatment of HIV-1-infected Jurkat cells with the necroptosis inhibitors Nec-1 (RIPK) or necrosulfamide (MLKL) strongly inhibits host cell syncytium formation, ${ }^{101}$ while siRNA depletion of RIPK1, RIPK3 and MLKL also reduces cell fusion. ${ }^{101}$ This suggests that necroptotic processes are utilized for this aspect of HIV-1 pathogenesis.

Autophagy, although not in itself a form of cell death, ${ }^{102}$ is a component of some true cell death processes, such as entosis. ${ }^{103}$ Some viruses have evolved to exploit autophagy to facilitate their own replication. Upon infection, encephalomyocarditis virus (EMCV) induces the formation of LC3- $\mathrm{II}^{+}$ autophagic vesicles. ${ }^{104}$ Autophagy is required for viral replication, as treatment with 3-methyladenine or siRNA-mediated inhibition of Atg7 or LC3 suppresses viral replication. Fascinatingly, it appears that EMCV uses these autophagic vesicles as a scaffold upon which viral genomic replication is performed. ${ }^{104}$

\section{Conclusion}

These strategies of caspase 'hijacking' could offer new avenues to explore towards understanding and controlling viral pathogenesis. The individual reports are encouraging, but sporadic. A systematic survey of caspase cleavage of viral proteins is warranted. As a start, we have performed an in silico screen for canonical caspase cleavage motifs within the proteomes of viruses of medical interest (Table 3). Many of these sites, of course, will not turn out to be cleaved in infected cells, as the presence of a caspase motif does not guarantee a cleavage event, let alone a functionally significant one. Nevertheless, the inverse is true; a cleavage event requires the present of a cleavage motif, so this survey may include some true positives among the false positives.

In vitro, the most basic criteria for identification of a caspasedependent viral process are:

(1) A reduction or defect of intracellular viral replication under caspase inhibition.

(2) The existence of one or more viral proteins which undergo caspase-dependent cleavage.

Based on these simple criteria, a screen for novel caspase cleavage events will be a relatively straightforward task.

\section{Conflict of Interest}

The authors declare no conflict of interest.

Acknowledgements. We apologize to our colleagues in the cell death and virology fields whose relevant work we could not cite due to space constraints. This work was supported by a PhD scholarship awarded to PC by the NUI Galway College of Science.

1. Earnshaw WC, Martins LM, Kaufmann SH. Mammalian caspases: structure, activation, substrates, and functions during apoptosis. Annu Rev Biochem 1999; 68: 383-424.

2. Martinon F, Tschopp J. Inflammatory caspases: linking an intracellular innate immune system to autoinflammatory diseases. Cell 2004; 117: 561-574.

3. Rudel T, Bokoch GM. Membrane and morphological changes in apoptotic cells regulated by caspase-mediated activation of PAK2. Science 1997; 276: 1571-1574.

4. Lee KK, Ohyama T, Yajima N, Tsubuki S, Yonehara S. MST, a physiological caspase substrate, highly sensitizes apoptosis both upstream and downstream of caspase activation. J Biol Chem 2001; 276: 19276-19285. 
5. Enari M, Sakahira H, Yokoyama H, Okawa K, Iwamatsu A, Nagata S. A caspase-activated DNase that degrades DNA during apoptosis, and its inhibitor ICAD. Nature 1998; 391: $43-50$.

6. Zhou BB, Li H, Yuan J, Kirschner MW. Caspase-dependent activation of cyclin-dependent kinases during Fas-induced apoptosis in Jurkat cells. PNAS 1998; 95: 6785-6790.

7. Galluzzi L, Brenner C, Morselli E, Touat Z, Kroemer G. Viral control of mitochondrial apoptosis. PLoS Pathog 2008; 4: e1000018.

8. Chiou SK, White E. Inhibition of ICE-like proteases inhibits apoptosis and increases virus production during adenovirus infection. Virology 1998; 244: 108-118.

9. Henderson S, Huen D, Rowe M, Dawson C, Johnson G, Rickinson A. Epstein-Barr viruscoded BHRF1 protein, a viral homologue of $\mathrm{Bcl}-2$, protects human $\mathrm{B}$ cells from programmed cell death. PNAS 1993; 90: 8479-8483.

10. Nava VE, Cheng EH, Veliuona M, Zou S, Clem RJ, Mayer ML et al. Herpesvirus saimiri encodes a functional homolog of the human bcl-2 oncogene. J Virol 1997; 71: 4118-4122.

11. Cheng EH, Nicholas J, Bellows DS, Hayward GS, Guo HG, Reitz MS et al. A Bcl-2 homolog encoded by Kaposi sarcoma-associated virus, human herpesvirus 8, inhibits apoptosis but does not heterodimerize with Bax or Bak. PNAS 1997; 94: 690-694.

12. Sarid R, Sato T, Bohenzky RA, Russo JJ, Chang Y. Kaposi's sarcoma-associated herpesvirus encodes a functional bcl-2 homologue. Nat Med 1997; 3: 293-298.

13. Marshall WL, Yim C, Gustafson E, Graf T, Sage DR, Hanify K et al. Epstein-Barr virus encodes a novel homolog of the bcl-2 oncogene that inhibits apoptosis and associates with Bax and Bak. J Virol 1999; 73: 5181-5185.

14. Nash P, Barrett J, Cao JX, Hota-Mitchell S, Lalani AS, Everett $\mathrm{H}$ et al. Immunomodulation by viruses: the myxoma virus story. Immunol Rev 1999; 168: 103-120.

15. Bertin J, Armstrong RC, Ottilie S, Martin DA, Wang Y, Banks S et al. Death effector domaincontaining herpesvirus and poxvirus proteins inhibit both Fas- and TNFR1-induced apoptosis. PNAS 1997; 94: 1172-1176.

16. Hu S, Vincenz C, Buller M, Dixit VM. A novel family of viral death effector domain-containing molecules that inhibit both CD-95- and tumor necrosis factor receptor-1-induced apoptosis. J. Biol Chem 1997; 272: 9621-9624.

17. Best SM, Bloom ME. Caspase activation during virus infection: more than just the kiss of death? Virology 2004; 320: 191-194.

18. Wall DM, McCormick BA. Bacterial secreted effectors and caspase-3 interactions. Cell Microbiol 2014; 16: 1746-1756.

19. Bloom M, Race R, Wolfinbarger J. Characterization of Aleutian disease virus as a parvovirus. J Virol 1980; 35: 836-843.

20. Qiu J, Cheng F, Burger LR, Pintel D. The transcription profile of Aleutian mink disease virus in CRFK cells is generated by alternative processing of pre-mRNAs produced from a single promoter. J Virol 2006; 80: 654-662.

21. Li L, Pesavento PA, Woods L, Clifford DL, Luff J, Wang C et al. Novel amdovirus in gray foxes. Emerg Infect Dis 2011; 17: 1876-1878.

22. Alexandersen S, Bloom ME, Wolfinbarger J. Evidence of restricted viral replication in adult mink infected with Aleutian disease of mink parvovirus. J Virol 1988; 62: 1495-1507.

23. Shimomura S, Wong S, Brown KE, Komatsu N, Kajigaya S, Young NS. Early and late gene expression in UT-7 cells infected with B19 parvovirus. Virology 1993; 194: 149-156.

24. Luo Y, Qiu J. Parvovirus infection-induced DNA damage response. Future Virol 2013; 8 245-257.

25. Best SM, Wolfinbarger JB, Bloom ME. Caspase activation is required for permissive replication of Aleutian mink disease parvovirus in vitro. Virology 2002; 292: 224-234.

26. Best SM, Shelton JF, Pompey JM, Wolfinbarger JB, Bloom ME. Caspase cleavage of the nonstructural protein NS1 mediates replication of Aleutian mink disease parvovirus. J Virol 2003; 77: 5305-5312

27. Kuiken T, Taubenberger JK. Pathology of human influenza revisited. Vaccine 2008; 26 : $59-66$

28. Bouvier NM, Palese P. The biology of influenza viruses. Vaccine 2008; $26: 49-53$.

29. Wurzer WJ, Planz O, Ehrhardt C, Giner M, Silberzahn T, Pleschka S et al. Caspase 3 activation is essential for efficient influenza virus propagation. EMBO $J$ 2003; 22: 2717-2728.

30. Zhirnov OP, Konakova TE, Garten W, Klenk H. Caspase-dependent N-terminal cleavage of influenza virus nucleocapsid protein in infected cells. J Virol 1999; 73 : 10158-10163.

31. Zhirnov OP, Syrtzev VV. Influenza virus pathogenicity is determined by caspase cleavage motifs located in the viral proteins. J Mol Genet Med 2009; 3: 124-132.

32. Olsen CW, Kehren JC, Dybdahl-Sissoko NR, Hinshaw VS. Bcl-2 alters influenza virus yield, spread, and hemagglutinin glycosylation. J Virol 1996; 70: 663-666.

33. McLean JE, Datan E, Matassov D, Zakeri ZF. Lack of Bax prevents influenza A virus-induced apoptosis and causes diminished viral replication. $J$ Virol 2009; 83: 8233-8246.

34. Mebratu YA, Tipper J, Chand HS, Walton S, Harrod KS, Tesfaigzi Y. Bik mediates caspasedependent cleavage of viral proteins to promote influenza A virus infection. Am J Respir Cell Mol Biol. 2016; 54: 664-673.

35. Zhirnov OP, Vorobjeva IV, Veselovski EM, Klenk HD. Key role of Asp16 in the cleavage of influenza A virus NP protein in infected cells. Probl Virol 2003; 48: 8-14.

36. Ozawa M, Fujii K, Muramoto Y, Yamada S, Yamayoshi S, Takada A et al. Contributions of two nuclear localization signals of influenza A virus nucleoprotein to viral replication. $J$ Virol 2007; 81: 30-41.
37. Lipatov AS, Yen HL, Salomon R, Ozaki H, Hoffmann E, Webster RG. The role of the $\mathrm{N}$-terminal caspase cleavage site in the nucleoprotein of influenza $\mathrm{A}$ virus in vitro and in vivo. Arch Virol 2008; 153: 427-434.

38. Zhirnov OP, Bukrinskaya AG. Two forms of influenza virus nucleoprotein in infected cells and virions. Virology 1981; 109: 174-179.

39. Kiyosawa K, Sodeyama T, Tanaka E, Gibo Y, Yoshizawa K, Nakano Y et al. Interrelationship of blood transfusion, non- $A$, non-B hepatitis and hepatocellular carcinoma: analysis by detection of antibody to hepatitis C virus. Hepatology 1990; 12: 671-675.

40. Reed KE, Rice CM. Overview of hepatitis C virus genome structure, polyprotein processing, and protein properties. Curr Top Microbiol Immunol 2000; 242: 55-84.

41. El-Hage N, Luo G. Replication of hepatitis $C$ virus RNA occurs in a membrane-bound replication complex containing nonstructural viral proteins and RNA. J Gen Virol 2003; 84 2761-2769.

42. Lindenbach $\mathrm{BD}$, Rice $\mathrm{CM}$. The ins and outs of hepatitis $\mathrm{C}$ virus entry and assembly. Nat Rev Microbiol 2013; 11: 688-700.

43. Honda M, Kaneko S, Shimazaki T, Matsushita E, Kobayashi K, Ping LH et al. Hepatitis C virus core protein induces apoptosis and impairs cell-cycle regulation in stably transformed Chinese hamster ovary cells. Hepatology 2000; 31: 1351-1359.

44. Benali-Furet NL, Chami M, Houel L, De Giorgi F, Vernejoul F, Lagorce D et al. Hepatitis C virus core triggers apoptosis in liver cells by inducing ER stress and ER calcium depletion Oncogene 2005; 24: 4921-4933.

45. Satoh S, Hirota M, Noguchi T, Hijikata M. Cleavage of hepatitis C virus nonstructural protein $5 \mathrm{~A}$ by a caspase-like protease in mammalian cells. Virology 2000; 487: 476-487.

46. Hidajat R, Nagano-Fujii M, Deng L, Hotta $\mathrm{H}$. Cleavage of the hepatitis $\mathrm{C}$ virus NS5A protein by caspase-3 in the interferon sensitivity-determining region in a sequencedependent manner. Kobe J Med Sci 2004; 50: 153-166.

47. Maqbool MA, Imache MR, Higgs MR, Carmouse S, Pawlotsky JM, Lerat $\mathrm{H}$. Regulation of hepatitis $\mathrm{C}$ virus replication by nuclear translocation of nonstructural $5 \mathrm{~A}$ protein and transcriptional activation of host genes. J Virol 2013; 87: 5523-5539.

48. Ghosh AK, Steele R, Meyer K, Ray R, Ray RB. Hepatitis C virus NS5A protein modulates cell cycle regulatory genes and promotes cell growth. J Gen Virol 1999; 80 : 1179-1183.

49. Lan KH, Sheu ML, Hwang SJ, Yen SH, Chen SY, Wu JC et al. HCV NS5A interacts with p53 and inhibits p53-mediated apoptosis. Oncogene 2002; 21: 4801-4811.

50. Chung YL, Sheu ML, Yen SH. Hepatitis C virus NS5A as a potential viral Bcl-2 homologue interacts with Bax and inhibits apoptosis in hepatocellular carcinoma. Int J Cancer 2003 107: 65-73.

51. Li Y, Zhang Q, Liu Y, Luo Z, Kang L, Qu J et al. Hepatitis C virus activates Bcl-2 and MMP-2 expression through multiple cellular signaling pathways. J Virol 2012; 86: 12531-12543.

52. American Cancer Society. Cancer Facts \& Figures 2014. American Cancer Society; 2014. Accessed: Atlanta, 2016

53. Lowy DR, Schiller JT. Reducing HPV-associated cancer globally. Cancer Prev Res 2012; 5 $18-23$.

54. Zheng ZM, Baker CC. Papillomavirus genome structure, expression, and posttranscriptional regulation. Front Biosci 2006; 11: 2286-2302.

55. Graham S. Human papillomavirus: gene expression, regulation and prospects for nove diagnostic methods and antiviral therapies. Future Microbiol 2010; 5: 1493-1506.

56. Schiller JT, Day PM, Kines RC. Current understanding of the mechanism of HPV infection. Gynecol Oncol 2010; 118: S12.

57. Doorbar J. The papillomavirus life cycle. J Clin Virol 2005; 32: S7-15.

58. Moody CA, Fradet-Turcotte A, Archambault J, Laimins LA. Human papillomaviruses activate caspases upon epithelial differentiation to induce viral genome amplification. PNAS 2007; 104: 19541-19546.

59. Scheffner M, Werness BA, Huibregtse JM, Levine AJ, Howley PM. The E6 oncoprotein encoded by human papillomavirus types 16 and 18 promotes the degradation of p53. Cell 1990; 63: 1129-1136.

60. Filippova M, Parkhurst L, Duerksen-Hughes PJ. The human papillomavirus 16 E6 protein binds to Fas-associated death domain and protects cells from Fas-triggered apoptosis. $J$ Biol Chem 2004; 279: 25729-25744.

61. Garnett TO, Filippova M, Duerksen-Hughes PJ. Accelerated degradation of FADD and procaspase 8 in cells expressing human papilloma virus 16 E6 impairs TRAlL-mediated apoptosis. Cell Death Differ 2006; 13: 1915-1926.

62. Ascher JM, Geneva AJ, Ng J, Wyatt JD, Glor RE. Phylogenetic analyses of novel squamate adenovirus sequences in wild-caught Anolis lizards. PloS One 2013; 8: e60977.

63. Ghebremedhin B. Human adenovirus: Viral pathogen with increasing importance. Eur J Microbiol Immunol 2014; 4: 26-33.

64. Russell WC. Adenoviruses: update on structure and function. J Gen Virol 2009; 90 $1-20$.

65. Meier O, Greber UF. Adenovirus endocytosis. J Gene Med 2003; 5: 451-462.

66. Grand R, Schmeiser K, Gordon E. Caspase-mediated cleavage of adenovirus early region 1 A proteins. Virology 2002; 271: 255-271.

67. Berk AJ. Recent lessons in gene expression, cell cycle control, and cell biology from adenovirus. Oncogene 2005; 24: 7673-7685.

68. Madeley CR. $28 \mathrm{~nm}$ particles in faeces in infantile gastroenteritis. Lancet 1975; 7932 451-452.

69. Kapoor A, Li L, Victoria J, Oderinde B, Mason C, Pandey P et al. Multiple novel astrovirus species in human stool. J Gen Virol 2009; 90: 2965-2972. 
70. Guix S, Bosch A, Pintó RM. Human astrovirus diagnosis and typing: current and future prospects. Lett Appl Microbiol 2005; 41: 103-105.

71. Méndez E, Aguirre-Crespo G. Association of the astrovirus structural protein VP90 with membranes plays a role in virus morphogenesis. J Virol 2007; 81: 10649-10658.

72. Méndez E, Muñoz-Yañez C, Sánchez-San Martín C, Aguirre-Crespo G Baños-Lara Mdel R, Gutierrez $\mathrm{M}$ et al. Characterization of human astrovirus cell entry. $J$ Virol 2014; 88: 2452-2460.

73. Dong J, Dong L, Méndez E, Tao Y. Crystal structure of the human astrovirus capsid spike. PNAS 2011; 108: 12681-12686.

74. Banos-Lara MDR, Méndez E. Role of individual caspases induced by astrovirus on the processing of its structural protein and its release from the cell through a non-lytic mechanism. Virology 2010; 401: 322-332.

75. Méndez E, Salas-Ocampo E, Arias CF. Caspases mediate processing of the capsid precursor and cell release of human astroviruses. J Virol 2004; 78: 8601-8608.

76. Engström BE. Blue wing disease of chickens: isolation of avian reovirus and chicken anaemia agent. Avian Pathol 1988; 17: 23-32.

77. Engström BE, Luthman M. Blue wing disease of chickens: signs, pathology and natural transmission. Avian Pathol 1984; 13: 1-12.

78. Teng L, Xie Z, Xie L, Liu J, Pang Y, Deng X et al. Complete genome sequences of an avian orthoreovirus isolated from Guangxi, China. Genome Announc 2013; 1: e00495-13.

79. Broering TJ, Kim J, Miller CL, Piggott CD, Dinoso JB, Nibert ML et al. Reovirus nonstructural protein mu NS recruits viral core surface proteins and entering core particles to factory-like inclusions. J Virol 2004; 78: 1882-1892.

80. Rodríguez-Grille J, Busch LK, Martínez-Costas J, Benavente J. Avian reovirus-triggered apoptosis enhances both virus spread and the processing of the viral nonstructural muNS protein. Virology 2014; 462-463: 49-59.

81. Tourís-Otero F, Cortez-San Martín M, Martínez-Costas J, Benavente J. Avian reovirus morphogenesis occurs within viral factories and begins with the selective recruitment of $\sigma \mathrm{NS}$ and $\lambda \mathrm{A}$ to $\mu \mathrm{NS}$ inclusions. $J \mathrm{Mol} \mathrm{Biol} 2004 ; 341: 361-374$.

82. Broering TJ, Arnold MM, Miller CL, Hurt JA, Joyce PL, Nibert ML. Carboxyl-proximal regions of reovirus nonstructural protein muNS necessary and sufficient for forming factorylike inclusions. J Virol 2005; 79: 6194-6206.

83. Center for Food Security \& Public Health. Classical Swine Fever. Factsheet. 2015; Ames, lowa. Available at http://www.cfsph.iastate.edu/Factsheets/pdfs/classical_swine_fever.pdf. Accessed 6 Dec 2016.

84. Xie J, Guo H, Gong W, Jiang D, Zhang L, Jia J et al. Identification of cleavage of NS5A of C-strain classical swine fever virus. Arch Virol 2016; 162: 391-400.

85. Slee EA, Adrain C, Martin SJ. Executioner caspase-3, -6, and -7 perform distinct, nonredundant roles during the demolition phase of apoptosis2001 J Biol Chem 276: 7320-7326.

86. Zhang $\mathrm{C}$, Kang K, Ning P, Peng $\mathrm{Y}$, Lin Z, Cui $\mathrm{H}$ et al. Heat shock protein 70 is associated with CSFV NS5A protein and enhances viral RNA replication. Virology 2015; 482: 9-18.

87. Cohen S, Marr AK, Garcin P, Panté N. Nuclear envelope disruption involving host caspases plays a role in the parvovirus replication cycle. J Virol 2011; 85: 4863-4874.

88. Mühlbauer D, Dzieciolowski J, Hardt M, Hocke A, Schierhorn KL, Mostafa A et al. Influenza virus-induced caspase-dependent enlargement of nuclear pores promotes nuclear export of viral ribonucleoprotein complexes. J Virol 2015; 89: 6009-6021.

89. Butin-Israeli V, Drayman N, Oppenheim A. Simian virus 40 infection triggers a balanced network that includes apoptotic, survival, and stress pathways. J Virol 2010; 84: 3431-3442.

90. Butin-Israeli V, Ben-nun-Shaul O, Kopatz I, Adam SA, Shimi T, Goldman RD et al Simian virus 40 induces lamin $\mathrm{A} / \mathrm{C}$ fluctuations and nuclear envelope deformation during cell entry. Nucleus 2011; 2: 320-330.

91. Bideshi DK, Tan Y, Bigot Y, Federici BA. A viral caspase contributes to modified apoptosis for virus transmission. Genes Dev 2005; 19: 1416-1421.

92. Bideshi DK, Demattei MV, Rouleux-Bonnin F, Stasiak K, Tan Y. Genomic sequence of Spodoptera frugiperda Ascovirus 1a, an enveloped, double-stranded DNA insect virus that manipulates apoptosis for viral reproduction. J Virol 2006; 80: 11791-11805.

93. Asgari S. A caspase-like gene from Heliothis virescens ascovirus (HvAV-3e) is not involved in apoptosis but is essential for virus replication. Virus Res 2007; 128: 99-105.

94. Hussain M, Garrad S, Asgari S. The role of actin filaments in ascovirus replication and pathology. Arch Virol 2009; 154: 1737-1743.

95. Thome M, Schneider P, Hofmann K, Fickenscher H, Meinl E, Neipel F et al. Viral FLICE-inhibitory proteins (FLIPs) prevent apoptosis induced by death receptors. Nature 1997; 386: 517-521.

96. Ennaciri J, Menezes J, Proulx F, Toledano BJ. Induction of apoptosis by herpes simplex virus-1 in neonatal, but not adult, neutrophils. Pediatr Res 2005; 59: 7-12.
97. Karlberg H, Tan YJ, Mirazimi A. Induction of caspase activation and cleavage of the viral nucleocapsid protein in different cell types during Crimean-Congo hemorrhagic fever virus infection. J Biol Chem 2011; 286: 3227-3234.

98. Arslan SY, Son KN, Lipton HL. During infection, Theiler's virions are cleaved by caspases and disassembled into pentamers. J Virol 2016; 90: 3573-3583.

99. Wolff S, Becker S, Groseth A. Cleavage of the Junin virus nucleoprotein serves a decoy function to inhibit the induction of apoptosis during infection. J Virol 2013; 87: 224-233.

100. Connolly PF, Jäger R, Fearnhead HO. New roles for old enzymes: killer caspases as the engine of cell behavior changes. Front Physiol 2014; 5: 149.

101. Pan T, Wu S, He X, Luo H, Zhang Y, Fan M et al. Necroptosis takes place in human immunodeficiency virus type-1 (HIV-1)-infected CD4+ T lymphocytes. PLoS One 2014; 9: e93944.

102. Kroemer G, Galluzzi L, Vandenabeele P, Abrams J, Alnemri E, Baehrecke E et al. Classification of cell death: recommendations of the Nomenclature Committee on Cell Death. Cell Death Differ 2008; 16: 3-11.

103. Overholtzer M, Mailleux AA, Mouneimne G, Normand G, Schnitt SJ, King RW et al. A non-apoptotic cell death process, entosis, that occurs by cell-in-cell invasion. Cell 2007; 131: 966-979.

104. Zhang $\mathrm{Y}$, Li Z, Ge X, Guo X, Yang H. Autophagy promotes the replication of encephalomyocarditis virus in host cells. Autophagy 2011; 7: 613-628.

105. Faucheu C, Diu A, Chan AW, Blanchet AM, Miossec C, Hervé $F$ et al. A novel human protease similar to the interleukin-1 beta converting enzyme induces apoptosis in transfected cells. EMBO J 1995; 14: 1914-1922.

106. Munday NA, Vaillancourt JP, Ali A, Casano FJ, Miller DK. Molecular cloning and pro-apoptotic activity of ICErelll and ICErellII, members of the ICE/CED-3 family of cysteine proteases. J Biol Chem 1995; 270: 15870-15876.

107. Igarashi $Y$, Eroshkin A, Gramatikova S, Gramatikoff K, Zhang Y, Smith JW et al. CutDB: a proteolytic event database. Nucleic Acids Res. 2007; 35: D546-D549.

108. Wang S, Miura M, Jung YK, Zhu H, Li E, Yuan J. Murine caspase-11, an ICE-interacting protease, is essential for the activation of ICE. Cell 1998; 92: 501-509.

109. Van de Craen M, Vandenabeele P, Declercq W, Van den Brande I, Van Loo G, Molemans F et al. Characterization of seven murine caspase family members. FEBS Lett 1997; 403: 61-69.

110. Humke EW, Ni J, Dixit VM. ERICE, a novel FLICE-activatable caspase. J Biol Chem 1998; 273: 15702-15707.

111. Wang L, Miura M, Bergeron L, Zhu H, Yuan J. Ich-1, an Ice/ced-3-related gene, encodes both positive and negative regulators of programmed cell death. Cell 1994; 78 : 739-750.

112. Boldin MP, Varfolomeev EE, Pancer Z, Mett IL, Camonis JH, Wallach D. A novel protein that interacts with the death domain of Fas/APO1 contains a sequence motif related to the death domain. J Biol Chem 1995; 270: 7795-7798.

113. Duan H, Orth K, Chinnaiyan AM, Poirier GG, Froelich CJ, He WW et al. ICE-LAP6, a novel member of the ICE/Ced-3 gene family, is activated by the cytotoxic $T$ cell protease granzyme B. J Biol Chem 1996; 271: 16720-16724.

114. Fernandes-Alnemri T, Armstrong RC, Krebs J, Srinivasula SM, Wang L, Bullrich F et al. In vitro activation of CPP32 and Mch3 by Mch4, a novel human apoptotic cysteine protease containing two FADD-like domains. PNAS 1996; 93: 7464-7469.

115. Eckhart L, Ballaun C, Uthman A, Kittel C, Stichenwirth M, Buchberger M et al. Identification and characterization of a novel mammalian caspase with proapoptotic activity. J Biol Chem 2005; 280: 35077-35080.

116. Fernandes-Alnemri T, Litwack G, Alnemri ES. CPP32, a novel human apoptotic protein with homology to Caenorhabditis elegans cell death protein Ced-3 and mammalian interleukin-1 beta-converting enzyme. J Biol Chem 1994; 269: 30761-30764.

117. Fernandes-Alnemri T, Litwack G, Alnemri ES. Mch2, a new member of the apoptotic Ced-3/ Ice cysteine protease gene family. Cancer Res 1995; 55: 2737-2742.

118. Fernandes-Alnemri T, Takahashi A, Armstrong R, Krebs J, Fritz L, Tomaselli KJ et al. Mch3, a novel human apoptotic cysteine protease highly related to CPP32. Cancer Res 1995; 55: 6045-6052.

119. Hu S, Snipas SJ, Vincenz C, Salvesen G, Dixit VM. Caspase-14 is a novel developmentally regulated protease. J Biol Chem 1998; 273: 29648-29653.

120. Eckhart L, Ballaun C, Hermann M, VandeBerg JL, Sipos W, Uthman A et al. Identification of novel mammalian caspases reveals an important role of gene loss in shaping the human caspase repertoire. Mol Biol Evol 2008; 25: 831-841. 